\title{
Virtual Peer Educator Training Program About Sexually Transmitted Infections in Adolescents
}

\author{
Nunung Nurhayati*, Ani Rahmawati, Astri Mutiar, Dewi Marfuah, and Linlin \\ Lindayani \\ STIKep PPNI Jawa Barat
}

\section{ORCID}

Nunung Nurhayati: https://orcid.org/0000-0001-7778-0971

Corresponding Author: Nunung Nurhayati; email:

nunky_adzra@yahoo.com

Published: 7 February 2022

Publishing services provided by Knowledge E

(c) Nunung Nurhayati et al. This article is distributed under the terms of the

Attribution License, which permits unrestricted use and redistribution provided that the original author and source are credited.

Selection and Peer-review under the responsibility of the IVCN Conference Committee.

\section{G OPEN ACCESS}

Abstract. Sexually transmitted infections (STIS) are caused by fungi, bacteria, parasites or viruses and are transmitted from one person to another through having intercourse. Lack of knowledge will cause teenagers to have sex unsafely. Teenagers need to be taught about reproductive health because STIs are common and there is little knowledge about STIs. This study aimed to find out the effectiveness of a virtual peer educator training program about STIs in teenagers. This was a quantitative quasiexperimental study. There were 38 participants who were aged $15-18$ years old and were recruited through convenience sampling. The data were collected by using two questionnaires: one about the awareness of STIs (Cronbach's alpha $=0.795$ ) and one about the attitudes towards STIs (Cronbach's alpha $=0.709$ ). The data were analyzed by using paired t-tests. This study showed that the training program was effective in enhancing teenagers' awareness and attitude about STIs. Educating teenagers about reproductive health is important to make they know about STIs, themselves and their surroundings.

Keywords: virtual, peer educator, training, STI, youth

\section{Background}

Sexually Transmitted Infections (STI) or often also called Sexually Transmitted Diseases are infections caused by fungi, bacteria, parasites, or viruses that are transmitted from one person to another through sexual intercourse. Often STIs do not cause symptoms, even if they cause symptoms it takes a long time, it can be months to years [1]. Sexually Transmitted Infections (STIs) are still a public health problem in various countries, according to WHO (2018) more than one million people with STIs in the world. Around 500 million STIs occur every year throughout Indonesia [2].

The city of Bandung is a big city, therefore, the city of Bandung cannot be separated from the problem of spreading STIs. The rate of development of sexually transmitted diseases in the city of Bandung in 2015 there were 821 cases of STDs and in 2016 there was an increase with the number of 2,621 cases. There was a decrease in the incidence of STIs in 2017 as many as 1,518 cases. Sexually Transmitted Infections in 
Bandung City in 2019 were 2,229. However, when compared to 2018, there was an increase in the number of STI cases in 2019, because the number of STI cases in 2018 was 1,317 STI cases. Sexually transmitted infections have become a separate problem for the government [3].

Knowledge is the result of information obtained through the senses it has [4]. Based on the Indonesian Demographic and Health Survey [5], adolescent knowledge (men and women aged $15-24$ years) about STIs is still low with data on $68 \%$ of women and $86 \%$ knowing of Syphilis; 34\% of women and 33\% of men know Gonorrhea; $21 \%$ of women and $12 \%$ of men know Genitalia Herpes. Meanwhile, knowledge of other types of STIs such as Condylomata, Chancroid, Chlamydia and Candida is still relatively low (below $5 \%$ each in women and men).

Based on research by [4] regarding the knowledge and attitudes of high school/ vocational high school students in a city in West Java conducted by students at a state university, it turns out that most of the students, $67.89 \%$, have less knowledge about diseases. sexually transmitted and $49.47 \%$ had less knowledge about the mode of transmission of STIs. Research conducted by [6] shows that most students have heard of STIs, but they know more about HIVIAIDS. Sexually Transmitted Infections other than HIV are only known by about $64 \%$ of students. Conditions such as LGV and chancroid are only known by $3 \%-7 \%$ of students. In addition, there are students who think that tuberculosis, leprosy and vitiligo are sexually transmitted diseases. If STIs are not immediately prevented and treated due to lack of knowledge, they can cause various complications such as disability, infertility, pregnancy disorders, growth disorders, HIV entry points, cervical cancer, and can even cause death [1]. Knowledge can be the basis for evaluating an object, which is produced in the form of an attitude [7].

Attitudes can be formed because of social interaction. In these social interactions, individuals form certain patterns of attitudes towards the psychological object they are facing. There are several factors that can influence the formation of attitudes, namely personal experience, the influence of people who are considered important, cultural influences, mass media, emotional factors, educational institutions and religious institutions [8]. Based on the results of research conducted by [9], the attitude of teenagers at SMAN 4 Cimahi City about IMS is around $32.2 \%$ of students have a bad or unsupportive attitude. Based on research conducted by [10] only about $16 \%$ of students feel masturbation is harmful to health and another $43 \%$ do not know about its effect on health. While $39.4 \%$ feel it does not interfere with health. One third of students thought it was okay to have premarital sex and $24.2 \%$ of students did not think so. Nearly $46 \%$ of students answered that they would wait until marriage to have sex. 
Lack of knowledge and bad attitudes of adolescents about sexuality issues puts adolescents at risk of having unsafe sex and changing partners, using illegal drugs, drinking excessive alcohol, having sex due to lifestyle and taking pills. Family planning to prevent sexually transmitted diseases [11]. Moreover, when adolescents grow up in a maladaptive environment, it will encourage the formation of immoral behavior that can damage the future of adolescents [1]. Therefore, adolescents should be given education from an early age to avoid promiscuity and can increase the knowledge and attitudes of adolescents about sexually transmitted diseases by providing health education.

Reproductive health and sexuality education in adolescents is important, because health education is a necessary part of achieving the task of growth and development in adolescents. The purpose of sexual education is to form a healthy emotional attitude towards sexual problems and guide adolescents to become adults who are healthy and responsible for their sexual lives [4]. There are several methods that have been carried out previously to conduct health education for adolescents, namely mentoring, discussion, strategy methods, peer teaching and simulation games. However, the phenomenon of peer education has become an effective health promotion among adolescents. This method makes adolescents as peer counselors who are expected to become agents of change in their group [6].

The results of the study [7] show that health education with the peer education method is very effective in increasing individual knowledge and attitudes in receiving the information submitted. The better the individual's knowledge, the attitudes, actions and behavior of individuals will also support to maintain reproductive health. Peer education is a method to provide information between peer groups led by a representative of the peer group who will be trained to lead in their peer group. With peer educators, adolescents will be more open and easier to communicate than adults. Information that is sensitive and uncomfortable when conveyed by adults can be conveyed by peers using age-appropriate language. Thus, information can be conveyed properly, easily understood and goals can be achieved. In addition, as a peer educator, peers not only provide information but also as role models in healthy behavior [8].

\section{Methods}

The methodology used is the quantitative methods a quasi experiment, planning use is one group pre test and post test. Research held in SMAN Bandung 19, because SMAN Bandung 19 is what one SMA in Bandung STI data in the greater Bandung high at is 2.229 cases.Time research conducted in april - may 2021. The population 
TABLE 1: Normality data

\begin{tabular}{|c|c|c|c|c|c|c|}
\hline & \multicolumn{3}{|c|}{ Skewness } & \multicolumn{3}{|c|}{ Kurtosis } \\
\hline & Statistic & Std. Error & Result & Statistic & Std. Error & Result \\
\hline Pre Knowledge &,- 215 &, 383 & $-0,561$ &,- 646 &, 750 & $-0,861$ \\
\hline Post Knowledge & ,432 &, 383 & 1,127 & 1,286 & ,750 & 1,714 \\
\hline Pre attitude &,- 786 &, 383 & $-2,052$ & ,818 &, 750 & 1,090 \\
\hline Post attitude & ,368 & ,383 & 0,960 & ,795 &, 750 & 1,06 \\
\hline Skill Rating Form & ,469 & ,383 & 1,224 & ,238 & ,750 & 0,317 \\
\hline
\end{tabular}

of the research is teenager was in public 19 Bandung. In this study sample who were respondents is already meet the criteria inclusion : A teenager was 15-18 years and students who willing to become respondents. Exclusion criteria were students was ill at the time of the study. Technique the sample in this research using convenience of sampling. As for many samples to this research researchers determine sample use $G$ power 3.1.9.4 with test family $F$ tests, statistical test ANOVA : Fixed effects, main effect and interactions, determine effect size $f 0,4$, $\alpha$ err prob 0,05 , Power (1- $\beta$ err prob) 0,8 Numerator df 1 , number of grops 2 , number of covariates 1 . A result in got the result of $\mathrm{G}$ power which has been credited brought total sample size is 34 with attrition rate 10 $\%$ total respondents 38 .

The questionnaire consisting of questions about characteristics of respondents, knowledge and attitude. Characteristics of respondents discuss information on respondents, age sex and source of information. The measurement of level of teenagers about STI by the number of questions as much as 8 question.The questionnaire developed by pandjaitan, niode, distilled (2017). The questionnaire use a choice between provided was " right " and "wrong". Every right answer they received a score 1 and wrong answer scored 0 .The questionnaire having Cronbach's Alpha 0,795. The measurement of attitude, an instrument used in the form of the questionnaire to the total number of questions as many as 8 questions. This questionnaire developed by pandjaitan, niode, distilled (2017) to question number 1 and 3 if the respondent said b " do not agree" punishment will be given the value 1 and to question number 2, 4, 5, 6, 7 and 8 when the respondents said a " agree " will be given the value 1 .While for the choice of answer apart from the provisions above will given a score of 0 .This questionnaire having Cronbach's Alpha 0,709.

While the researchers have do normality data on the variables of knowledge, the attitudes and virtual peer educators in the way that counts $\frac{\text { skewness skor }}{\text { standar eror }}$. 
TABLE 2: Characteristics of Teenage Respondents Who Are Actively Organized at SMAN 19 Bandung N=38

\begin{tabular}{l|l|l|l} 
Variable & Categorical & N & Percentage \\
Usia 15 16 17 Sex & $\begin{array}{l}\text { X Class XI Class 616 16 830 } \\
\text { XII Class Male } \\
\text { Female }\end{array}$ & $\begin{array}{l}15,842,142,121,1 \\
78,9\end{array}$ \\
Variable & Mean (SD) & Mininum & Maximum \\
Age & $16,26 \pm, 724$ & 15 & 17
\end{tabular}

TABLE 3: Distribution of Adolescent Information Sources Regarding STIs N=38

\begin{tabular}{|c|c|c|c|}
\hline Variable & Categorical & $\mathbf{N}$ & Percentage \\
\hline Source Information & $\begin{array}{l}\text { Friends School } \\
\text { Mass Media } \\
\text { Friends, School, } \\
\text { Massa Media }\end{array}$ & 114617 & $\begin{array}{lll}28,9 & 10,5 & 15,8 \\
44,8 & & \end{array}$ \\
\hline
\end{tabular}

Based on table 1 on knowledge pre post, attitude pre post and virtual peer educator training normal distribution. If scores the division between -2 until 2 so normal distribution data said.

\section{Results}

The research results virtual peer educator training program about sexually transmitted infection in teen, with samples from 38respondents. This study using descriptive, quantitative in SMAN 19 Bandung for 6 meetings.

\subsection{Characteristics of Respondents}

Table 2 on shows that of 38 respondents the average age of 16 years. The majority of respondents of the female sex as many as 30 (78,9\%).

Tabel 3 on shows respondents receiving a source of information from a mixture of ( friend, school parents, the mass media ) as many as people 17 ( $44,8 \%$ ).

\section{Peer Educator Training Program}

TABLE 4: The Distribution of Skill Rating from Training Post Training N=38

\begin{tabular}{l|l|l|l|}
\hline Variable & Mean (SD) & Mininum & Maximum \\
\hline Skill Rating Form & $50,37 \pm 2,870$ & 45 & 58
\end{tabular}


TABLE 5: Distribution of Domain Skill Rating Form $\mathrm{N}=38$

\begin{tabular}{|c|c|c|}
\hline Min -- Max M & Mean (SD) & \\
\hline Training Techniques Team work & $20-2724-21$ & $22,82 \pm 1,55718,11 \pm 1,467$ \\
\hline Managing Participants & $8-12$ & $9,39 \pm 1,220$ \\
\hline
\end{tabular}

\subsection{Observations}

Table 4 The above shows that the virtual peer educator training variable average value is 50.37 with an SD value of 2.870 , the SD value is greater than the average value, which means that the distribution of data is uneven, because the difference between one data and another is greater than the average value flat.

At the last meeting the respondents made presentations and also discussions, the researchers assessed that the students used the skill rating form to evaluate the peer educator's skills starting from the training techniques (Training Techniques). sound volume. Furthermore, all team work (Team Work) is good in teamwork, working together, both group assignments and discussions. There is also the way students manage participants (Managing Participants) all of them are quite good at managing participants. From the overall results of the peer educator training assessment, the participants were good in applying this peer educator training to their peers.

Table 5 The above shows the average value of the training technique is 22.82 with an SD value of 1.557. The average value of teamwork is 18.11 with an SD value of 1.467. The average score for managing participants is 9.39 with an SD score of 1.220 , the SD score is greater than the average value, which means that the distribution of the data is uneven, because the difference between the data is greater than the average value.

Table 6 shows that the training technique that has the largest value is eye contact points with an average value of 2.61 with an SD value of 0.495 , the smallest value is in listening skills points with an average value of 2.45 with an SD value of .504 . Furthermore, in teamwork which has the greatest value, there are practical assistance points and agenda changes with an average value of 2.63 with an SD value of 0.489 , the smallest value is found in cooperation points with colleagues with an average value of 2.53 with an SD score. ,506. As for managing participants, the largest score was found in the learning environment points with an average score of 2.42 with an SD score of 0.489 while the smallest value was found in the point of giving feedback with an average value of 2.26 with an SD score of 0.446 .

One of the indicators to become a peer educator is to have competent knowledge and attitude. Therefore, the researchers analyzed changes in knowledge and attitudes 
TABLE 6: Distribution of Skill Rating For

\begin{tabular}{|c|c|c|}
\hline Categorical & Min -- Max & Mean (SD) \\
\hline \multicolumn{3}{|l|}{ Training Techniques } \\
\hline $\begin{array}{lr}\text { Explain the purpose } \\
\text { Eye contact } \\
\text { Listening }\end{array}$ & $\begin{array}{l}2-32-32- \\
32-31-32 \\
-32-32-3 \\
2-3\end{array}$ & $\begin{array}{l}2,55 \pm, 5042,61 \\
\pm, 4952,55 \pm 504 \\
2,45 \pm, 5042,50 \\
\pm, 558 \quad 2,55 \quad \pm \\
, 5042,53 \pm, 506 \\
2,53 \pm, 5062,55 \\
\pm, 504\end{array}$ \\
\hline \multicolumn{3}{|l|}{ Team work } \\
\hline $\begin{array}{l}\text { Collaboration with } \\
\text { colleagues Practical } \\
\text { help Sharing the } \\
\text { training ground } \\
\text { Mutual respect Smooth } \\
\text { teamwork Activities } \\
\text { according to the } \\
\text { agenda Change of } \\
\text { agenda }\end{array}$ & $\begin{array}{l}2-32- \\
32-32 \\
-3\end{array}$ & $\begin{array}{l}2,53 \pm, 5062,63 \\
\pm \quad, 489 \quad 2,58 \pm \\
, 5002,58 \pm, 500 \\
2,58 \pm, 5002,58 \\
\pm, 500 \quad 2,63 \pm \\
489\end{array}$ \\
\hline \multicolumn{3}{|l|}{ Managing Participants } \\
\hline $\begin{array}{l}\text { Learning environment } \\
\text { Overcoming the atmo- } \\
\text { sphere Motivate partic- } \\
\text { ipants Give feedback }\end{array}$ & $\begin{array}{l}2 \\
3\end{array}$ & $\begin{array}{l}2,42 \pm, 4892,39 \\
\pm, 4952,32 \pm, 471 \\
2,26 \pm, 446\end{array}$ \\
\hline
\end{tabular}

TABLE 7: Distribution of Adolescent Knowledge and Attitudes About ISK N=38

\begin{tabular}{l|l|l|l|l|l} 
Variable & \multicolumn{2}{|c|}{ Pre test } & \multicolumn{2}{c}{ Post test } & P-value \\
& Mean SD & Min \pm max & Mean SD & Min \pm max & p-value \\
Knowledge & $6,11 \pm 1,158$ & $4 \pm 8$ & $7,13 \pm, 4756 \pm 8$ & .000 \\
\hline Attitude & $6,76 \pm, 751$ & $5 \pm 8$ & $7,16 \pm, 4956 \pm 8$ & .000
\end{tabular}

to see that the peer educator could be a good peer educator or not. From the results of the analysis of knowledge and attitudes obtained the following results :

above shows the average value variable in pre-knowledge is 6.11 with a Standard Deviation (SD) of 1.158, in post-knowledge the average value is 7.13 with an SD value of 0.475 , the value of knowledge shows that there is an increase in which the greater the value knowledge is higher. The average pre-attitude value is 6.76 with an SD value of 0.751 , the post-attitude value shows 7.16 with an SD value of 0.495 , the attitude value shows that there is an increase in which the greater the attitude value, the more positive the attitude. From the results of the pre and post frequency distributions and also seen from the results of the paired sample test, it turns out that there are significant differences in both pre and post knowledge and attitudes. This program is quite effective in producing good peer educators. 
There is a significant difference between pre-knowledge and post-knowledge using the Paired Sample Test with the result of Sig (2-tailed) 0.000 . There is a significant difference between pre-attitude and post-attitude using the Paired Sample Test with the result of Sig (2-tailed) 0.000 .

\section{Discussion}

This study was conducted at the age of adolescence where another adolescent cognitive development is the emergence of adolescent egocentrism, which describes the increased self-awareness and belief of adolescents that other people have as much attention as their own attention to their personal feelings and uniqueness [9]. So teenagers can think systematically, by doing various kinds of combinations, understanding the various aspects of a problem that can be solved instantly, at once, no longer one by one as is usually done in children during the concrete operation period [10].

Knowledge of SMAN 19 Bandung adolescents who were given virtual peer educator training increased with an average value of 6.11 to 7.13 . Meanwhile, the average score was 6.76 to 7.16 , which is an effective program to implement because the students of SMAN 19 Bandung have the knowledge and attitudes that are qualified to become peer educators. This means that the material provided in this study can improve knowledge and attitudes so that the material is quite effective and suitable to become a standard for peer educator training. If the peer educator has sufficient knowledge, then the peer educator will be able to provide knowledge about STIs to their peers. Adolescent knowledge about reproductive health can influence and is also influenced by the knowledge of their peers [11].

The results of this study are in line with research conducted by [12]. The implementation of peer educator training activities can increase the knowledge and attitudes of adolescents in providing solutions to cases encountered through peer educator activities. Research conducted by [13] found that adolescents are no longer awkward to consult with peer educators about the problems they face, especially regarding reproductive health and after counseling on reproductive health, these adolescents become more aware of the importance of maintaining reproductive health. In a study conducted by [13] there was an increase in the average value of knowledge from 7.02 to 12.32 where the average value showed an increase in knowledge about STI in female sex workers (FSW). 
Knowledge can be the basis for evaluating an object, which is produced in the form of an attitude [12]. Although the change in attitude did not change drastically at the same time, because peer education is only a means used to make a person's process or progress towards a better direction so that the changes that will occur in the future can be positive or negative. Good knowledge and attitude will prevent teenagers from premarital sex behavior. This is because knowledge and attitudes are motivating factors to act, both positive and negative, which are contained in a person or are called predisposing factors [11].

The results of this study are in line with research conducted by [10] that the peer education method can improve student attitudes with $\mathrm{p}$-value $<0.05$. In a study conducted by [12], 51.3\% of adolescents had negative attitudes towards STI and HIV/AIDS. The research conducted by [13] found that respondents' attitudes were in the good category of $75.22 \%$.

In the results of the skill rating form domain, the training technique points to eye contact points with the highest score because eye contact reflects comfort when talking to other people, and listening skills points with the lowest score because they are easily distracted by various factors, the environment is unsupportive and unfocused when listening to people. other. Furthermore, in the teamwork domain, the highest score is on practical assistance points and also agenda changes. Because effective communication is very much needed in the program, agenda changes must always be communicated, while the lowest score is on points of cooperation with colleagues due to lack of awareness and sense of responsibility of team members, communication not smooth and also less concerned about his team. Then in the domain of managing participants, the highest score is found in the learning environment point because by using the environment as a learning resource for students, it will add and enrich other learning resources in learning, with a learning environment it will overcome the boredom of learning in class. The lowest score is on the point of giving feedback because respondents have difficulty learning individually by responding to work results.

\section{Conclusion}

According to the virtual research peer educator training program about sexually transmitted infection in teen, we can conclude that the implementation of virtual activities peer educator training this program effective enough to increase knowledge and attitudes about Sexually Transmitted Infections. Because one of indicators to be a peer educator who good is having knowledge and attitudes. 


\section{References}

[1] Berek PAL, Be MF, Rua YM, Anugrahini C. Hubungan Jenis Kelamin Dan Umur Dengan Tingkat Pengetahuan Remaja Tentang Hiv/Aids Di Sman 3 Atambua Nusa Tenggara Timur 2018. J Sahabat Keperawatan. 2019;1(01):4-13.

[2] Ghasemi V, Simbar M, Rashidi Fakari F, Saei Ghare Naz M, Kiani Z. The effect of peer education on health promotion of Iranian adolescents: A systematic review. Int J Pediatr. 2019;7(3):9139-57.

[3] Dinas Kesehatan Kota Bandung. Profil Kesehatan Kota Bandung [Internet]. 2019. Available from: https://dinkes.bandung.go.id/wp-content/uploads/2020/09/ProfilKesehatan-Kota-Bandung-Tahun-2019.pdf

[4] Irwansyah L. Kemiskinan, Keluarga Dan Prostitusi Pada Remaja. Psychol Humanit. 2016;2:19-20.

[5] National Population and Family Planning Board (BKKBN), Statistics (BPS) M, (Kemenkes) and I. Indonesia District Health Survey 2017. 2018;588. Available from: https://dhsprogram.com/pubs/pdf/FR342/FR342.pdf

[6] Marlita L. Pengaruh peer education terhadap perilaku seksual remaja di SMAK Abdurrab Kota Pekanbaru Provinsi Riau. J Keperawatan Abdurrab. 2017;1(1):71-82.

[7] Rahmi U, Gustini K, Puspita APW. Pengetahuan Siswa kelas XI Tentang Penyakit Menular Seksual. J Pendidik Keperawatan Indones. 2015;1(2):105-15.

[8] Ramadhani A, Ramadani ML. Pengaruh Pendidikan Kesehatan Dengan Metode Ceramah Dan Audiovisual Terhadap Pengetahuan Tentang Infeksi Menular Seksual Pada Remaja. J Keperawatan Muhammadiyah. 2020;

[9] Rofi'ah S. Efektivitas pendidikan kesehatan metode peer group terhadap tingkat pengetahuan dan sikap personal hygiene saat menstruasi. J IIm Bidan. 2017;2(2):316.

[10] Setianingrum VM. KOMUNIKASI PEMBELAJARAN MELALUI VIRTUAL LEARNING. Translitera J Kaji Komun dan Stud Media. 2019;8(02):44-54.

[11] Sofia A, Adiyanti MA. Hubungan pola asuh otoritatif orang tua dan konformitas teman sebaya terhadap kecerdasan moral. J Pendidik progresif. 2014;4(2):133-41.

[12] Sumartini S, Maretha V. Efektifitas Peer Education Method dalam Pencegahan HIVIAIDS terhadap Pengetahuan Dan Sikap Remaja. J Pendidik Keperawatan Indones. 2020;6(1):77-84.

[13] Wahyuningsih DD. Pendidikan seksualitas pada remaja melalui media pembelajaran. In: Prosiding Seminar Nasional Bimbingan dan Konseling. 2017. p. 46-51. 